\title{
Physical map of the genome of Oenococcus oeni PSU-1 and localization of genetic markers
}

\author{
Líbia Zé-Zé, ${ }^{1,2}$ Rogério Tenreiro, ${ }^{1,2,3}$ Luisa Brito, ${ }^{2}+$ Mário A. Santos ${ }^{1,3}$ \\ and Helena Paveia ${ }^{1,2}$
}

Author for correspondence: Rogério Tenreiro. Tel: +35117573141 . Fax: +35117500048. e-mail : rpat@correio.cc.fc.ul.pt

1 Departamento de Biologia Vegetal, Faculdade de Ciências da Universidade de Lisboa, Edifício C2, Piso 4, Campo Grande, 1700 Lisboa, Portugal

2 Centro de Genética e Biologia Molecular, UL, 1700 Lisboa, Portugal

3 Instituto de Tecnologia Química e Biológica, 2780 Oeiras, Portugal

\begin{abstract}
A physical map of the chromosome of Oenocccus oeni PSU-1 was constructed. This represents the first map for a strain of this species. A total of 37 restriction sites for the rare-cutting endonucleases Ascl, Fsel, Notl and Sfil were mapped on the chromosome, which was found to be circular with an estimated size of $1857 \mathrm{~kb}$. Fragment order was determined using several approaches: analysis of partial and double digestions, two-dimensional pulsedfield gel electrophoresis, isolation of linking clones, and Southern hybridization with labelled restriction fragments both from PSU-1 and from 0. oeni strain GM. Oenococcal genes alsS/alsD, mleA and mir, two phage attachment sites and recurrent sequences such as IS1165-like elements and rrn loci were located on the physical map. Specific fragments hybridizing with gene probes from Lactococcus lactis, Leuconostoc mesenteroides and Bacillus subtilis were also identified. The two ribosomal operons have been precisely located and their transcription direction determined.
\end{abstract}

Keywords: Oenococcus oeni, physical map, genetic map, rrn organization

\section{INTRODUCTION}

Oenococcus oeni, formerly known as Leuconostoc oenos (Dicks et al., 1995), is a lactic acid bacterium occurring naturally in wine and related habitats, which is characterized by its peculiar acidophilic nature and growth in media containing high ethanol levels (Garvie, 1986). These properties, associated with the ability to carry out malolactic fermentation and a suggested enhancement of the organoleptic properties of wine, has promoted its use in starter cultures for wine-making (Kunkee, 1991).

Recent research concerning $O$. oeni has been focused in five main fields: (i) bioenergetics of organic acid transport and elucidation of metabolic pathways (Ramos \& Santos, 1996; Salema et al., 1996; Veiga da Cunha et al., 1993); (ii) analysis of evolutionary divergence and tachytely (Martinez-Murcia et al., 1993; Morse et al., 1996; Zavaleta et al., 1996); (iii) assessment of intraspecific variability and development of reliable typing methods (Kelly et al., 1993; Tenreiro et al., 1994;

†Present address: Departamento de Botânica e Engenharia Biológica Microbiologia, Instituto Superior de Agronomia, 1399 Lisboa, Portugal.

Abbreviations: 2D, two dimensional; CHEF, contour-clamped homogeneous electric field; TAFE, transverse alternating field.
Viti et al., 1996; Zavaleta et al., 1997); (iv) molecular characterization of plasmids and phages (Brito et al., 1996; Fremaux et al., 1993; Santos et al., 1996; Zúñiga et al., 1996); and (v) analysis of genes related to its oenological properties and stress response (Garmyn et al., 1996; Jobin et al., 1997; Labarre et al., 1996).

Despite the multidisciplinary interest in this species, a major drawback remains, in that no effective means of genetic transfer has been reported so far for O. oeni. Classical genetic tools are also hampered by the requirement of this species for rich growth media (Garvie, 1986). Therefore, only analysis of isolated genes and construction of physical and genetic maps by the topdown method (Cole \& Saint-Girons, 1994) may allow some progress in the understanding of genome expression and structure, dynamics of chromosome rearrangements and intraspecific variability in O. oeni.

Pulsed-field gel electrophoresis (PFGE) techniques represent powerful tools for estimation of genome size and construction of physical and genetic maps. In lactic acid bacteria, such maps are only available for strains of Lactococcus lactis and Streptococcus thermophilus (Davidson et al., 1996; Le Bourgeois et al., 1992; Roussel et al., 1994, 1997; Tulloch et al., 1991).

This paper presents a physical map of O. oeni PSU-1, a 
strain commonly used as starter in wine-making and for which the macrorestriction profile with endonucleases that recognize GC-rich sequences was already known (Tenreiro et al., 1994). Oenococcal genetic markers, as well as putative genes inferred from hybridization studies with probes from heterologous Gram-positive bacteria, were located on the map constructed.

\section{METHODS}

Bacterial strains and growth conditions. O. oeni strains PSU1 (provided by R. Kunkee, University of California at Davis, USA), GM (Microlife Techniques, Sarasota, FL, USA) and L217 ${ }^{\mathrm{T}}$ (Collección Española de Cultivos Tipo, Valencia, Spain) were grown at $28^{\circ} \mathrm{C}$ in MTJ broth $\mathrm{pH} 5.5$ (Tenreiro et al., 1993). Escherichia coli JM109 was grown at $37^{\circ} \mathrm{C}$ in LB broth, supplemented with $100 \mu \mathrm{g}$ ampicillin $\mathrm{ml}^{-1}$ when required.

Preparation and restriction of genomic DNA. Intact genomic DNA was prepared and digested with restriction endonucleases as previously described (Tenreiro et al., 1994), except that 5-10 U of AscI and FseI were used for each agarose plug. Partial digestions with AscI were similarly performed using 2-10 $\mathrm{U}$ enzyme for $0 \cdot 5-2 \mathrm{~h}$. Double digestions were performed sequentially by washing the agarose plugs with $\mathrm{TE}$ (10 mM Tris/ $\mathrm{HCl}, 1 \mathrm{mM}$ EDTA, pH 8.0) and changing the buffer to the appropriate one between incubations. All enzymes were purchased from New England BioLabs.

Pulsed-field gel electrophoresis. PFGE was carried out using the Gene Navigator system (Pharmacia) with contourclamped homogeneous electric field (CHEF), and Geneline (Beckman) with transverse alternating field (TAFE). The CHEF system was used with $1 \%(\mathrm{w} / \mathrm{v}$ ) agarose gels (Seakem GTG, FMC) and $0.5 \times$ TBE (45 mM Tris, $45 \mathrm{mM}$ boric acid, $1 \mathrm{mM}$ EDTA, $\mathrm{pH} 8 \cdot 0$ ). Three run-types were applied for resolution of fragments in different ranges $(<150 \mathrm{~kb}$, $150-750 \mathrm{~kb},>750 \mathrm{~kb}$ ), as previously described (Tenreiro et al., 1994). The TAFE system was used with $1 \%(\mathrm{w} / \mathrm{v})$ agarose gels (Seakem LE, FMC) and $1 \times$ TAE (40 mM Tris, $20 \mathrm{mM}$ acetic acid, $1 \mathrm{mM}$ EDTA, pH 8.0). In this case, separation of fragments was performed using a two-phase run. In the first phase, at $195 \mathrm{~mA}$, pulse time varied from 1 to $9 \mathrm{~s}$ for $5 \mathrm{~h}$, by increments of $1 \mathrm{~s}$; in the second, at $120 \mathrm{~mA}$, pulse time varied by $2 \mathrm{~s}$ increments from 10 to $20 \mathrm{~s}$. Electrophoresis was performed at $10^{\circ} \mathrm{C}$ in both systems.
The mean size of each fragment was estimated from several gels by linear interpolation with two flanking size standards (Heath et al., 1992). The chromosomes of Saccharomyces cerevisiae (Bio-Rad), lambda DNA, and mid-range and lowrange PFG ladders (New England BioLabs) were used as size markers.

The two-dimensional PFGE (2D-PFGE) as described by Bautsch (1988) was initially used in this work. Later, owing to ambiguities in assigning the spots arising from this procedure to specific fragments of double digests having similar mobilities, the following version was adopted. Restriction fragments obtained with one enzyme were individually excised from the gel and, after sequential digestion with another enzyme, submitted to the second electrophoresis. The doubledigested fragments were inserted in the gel ordered by size, to reconstruct the original restriction profile. Single and double digestions were co-electrophoresed. The designation 2DPFGE has been adopted throughout this paper, irrespective of the version used.

Isolation of linking clones. Genomic DNA of strain PSU-1 was partially digested with Sau3AI and fragments of aproximately $6 \mathrm{~kb}$ were recovered after centrifugation in a sucrose gradient (Ohman, 1988). After incubation with T4 DNA ligase (New England BioLabs), the self-ligated DNA was digested with NotI and cloned into a NotI-cleaved pBluescript KS II vector (Stratagene). This mixture was used to transform E. coli JM109 by electroporation using the ProGenetor II system (Hoefer Scientific Instruments).

Probes. Plasmids containing fragments used as probes are listed in Table 1.pRT1 was obtained by cloning in pBluescript SK II (Stratagene) a $1342 \mathrm{bp}$ PCR product resulting from amplification of $O$. oeni $\mathrm{L} 217^{\mathrm{T}}$ genomic DNA, with primers $5^{\prime}$ TTGATCCTGGCTCAGGAT- $3^{\prime}$ and $5^{\prime}$-ACTTCGTGGAGTCGAGTT-3', corresponding to positions $13-30$ and 1337-1354 of the published 16S RNA sequence (MartinezMurcia \& Collins, 1990). pZZ1 was constructed by inserting in the same vector a 1123 bp EcoRI fragment, corresponding to positions 104-1226 of the published 23S RNA sequence (Martinez-Murcia et al., 1993). This fragment was originally present in a lambda clone selected from a genomic bank of $O$. oeni PSU-1 in lambda DASH II (Stratagene) by hybridization with the $1342 \mathrm{bp}$ rrs probe. Comparison of the insert restriction map with that expected from published sequences revealed that the clone contained an intact $r r n$ operon.

Table 1. Plasmids used in this study

\begin{tabular}{|c|c|c|c|c|}
\hline Plasmid & Gene (function) description & Source of relevant marker & $\begin{array}{l}\text { Stringency } \\
\text { conditions* }\end{array}$ & Reference \\
\hline pRT1 & $r r s$ & Oenococcus oeni $\mathrm{L} 217^{\mathrm{T}}$ & $\mathrm{H}$ & This study \\
\hline $\mathrm{pZZ1}$ & $r r l$ & O. oeni PSU-1 & $\mathrm{H}$ & This study \\
\hline pLB3 & $\operatorname{mir}($ resistance to mitomycin $\mathrm{C})$ & O. oeni PSU-1 & $\mathrm{H}$ & Brito (1996) \\
\hline $\mathrm{pJ} 2 \mathrm{C} 3$ & mle $A$ (malolactic enzyme) & O. oeni Lo84.13 & $\mathrm{H}$ & Labarre et al. (1996) \\
\hline pGID600 & $\begin{array}{l}\text { als } S, \text { als } D \text { ( } \alpha \text {-acetolactate } \\
\text { synthase and decarboxylase) }\end{array}$ & O. oeni Lo84.13 & $\mathrm{H}$ & Garmyn et al. (1996) \\
\hline pDU36-1 & $r e c A$ (DNA recombination) & Leuconostoc mesenteroides & $\mathrm{L}$ & P. Duwat (unpublished) \\
\hline pAK6.9 & IS1165 (insertion sequence) & L. mesenteroides & $\mathbf{L}$ & Johansen \& Kibenich (1992) \\
\hline pFS21 & citP (citrate permease) & Lactococcus lactis & $\mathbf{L}$ & Sesma et al. (1990) \\
\hline pSNL4 & $\operatorname{ara} A$ ( $\mathrm{L}$-arabinose isomerase) & Bacillus subtilis & $\mathbf{L}$ & I. Sá-Nogueira (unpublished) \\
\hline
\end{tabular}

${ }^{*} \mathrm{H}$, high stringency; $\mathrm{L}$, low stringency. 
Table 2. Sizes (kb) of restriction fragments obtained by cleavage of the chromosome of 0. oeni PSU-1

The observed sizes are mean values of restriction fragments, calculated from 2-19 determinations. The maximal deviation in size was estimated to be less than $4 \%$. The map sizes are theoretical sizes of fragments calculated by placing the restriction sites on the map.

\begin{tabular}{|c|c|c|c|c|c|c|c|c|}
\hline \multirow[t]{2}{*}{ Fragment } & \multicolumn{2}{|c|}{ AscI } & \multicolumn{2}{|c|}{ FseI } & \multicolumn{2}{|c|}{ NotI } & \multicolumn{2}{|l|}{ SfiI } \\
\hline & $\begin{array}{l}\text { Observed } \\
\text { size }\end{array}$ & $\begin{array}{c}\text { Map } \\
\text { size }\end{array}$ & $\begin{array}{l}\text { Observed } \\
\text { size }\end{array}$ & $\begin{array}{c}\text { Map } \\
\text { size }\end{array}$ & $\begin{array}{l}\text { Observed } \\
\text { size }\end{array}$ & $\begin{array}{c}\text { Map } \\
\text { size }\end{array}$ & $\begin{array}{l}\text { Observed } \\
\text { size }\end{array}$ & $\begin{array}{c}\text { Map } \\
\text { size }\end{array}$ \\
\hline 1 & 990 & 987 & 680 & 692 & 795 & 798 & 330 & 330 \\
\hline 2 & 513 & 520 & 352 & 353 & 270 & 265 & 295 & 295 \\
\hline 3 & 214 & 220 & 240 & 233 & 250 & 252 & 280 & 271 \\
\hline 4 & 130 & 130 & 235 & 230 & 133 & 135 & 160 & 160 \\
\hline 5 & & & 163 & 157 & 128 & 128 & 137 & 137 \\
\hline 6 & & & 99 & 99 & 102 & 102 & 130 & 130 \\
\hline 7 & & & 75 & 75 & 58 & 58 & 110 & 110 \\
\hline 8 & & & 18 & 18 & 44 & 44 & 100 & 100 \\
\hline 9 & & & & & 44 & 44 & 72 & 72 \\
\hline 10 & & & & & 15 & 15 & 62 & 62 \\
\hline 11 & & & & & 10 & 10 & 44 & 44 \\
\hline 12 & & & & & 6 & 6 & 44 & 44 \\
\hline 13 & & & & & & & 35 & 35 \\
\hline 14 & & & & & & & 35 & 35 \\
\hline 15 & & & & & & & 26 & 26 \\
\hline 16 & & & & & & & 6 & 6 \\
\hline Total & 1847 & 1857 & 1862 & 1857 & 1855 & 1857 & 1866 & 1857 \\
\hline
\end{tabular}

Labelling and hybridization. Gene probes were excised from cloning vectors with suitable enzymes and after agarose gel electrophoresis recovered with the Sephaglas BandPrep kit (Pharmacia). Labelling with $\left[\alpha-{ }^{32} \mathrm{P}\right] \mathrm{dCTP}$ was performed using the Multiprime labelling system (Amersham). Some restriction fragments generated by the enzymes AscI, NotI and SfiI from chromosomal DNA of strains PSU-1 and GM were also used as probes for mapping purposes. These fragments were excised, recovered and labelled as above. PFGE gels were treated as described by Wahl et al. (1987) and restriction fragments were transferred to a nylon membrane (Hybond-N, Amersham) by blotting overnight with $10 \times \operatorname{SSC}(1.5 \mathrm{M} \mathrm{NaCl}$, $0.15 \mathrm{M}$ sodium citrate). Hybridizations were performed as previously described (Santos et al., 1996), at $68^{\circ} \mathrm{C}$ for high stringency (homologous probes) and at $50^{\circ} \mathrm{C}$ for low stringency (heterologous probes). Filters were washed at the hybridization temperature, twice in $2 \times$ SSC for $15 \mathrm{~min}$, twice in $2 \times \mathrm{SSC} / 0.1 \%(\mathrm{w} / \mathrm{v}) \mathrm{SDS}$ for $30 \mathrm{~min}$, and once in $0.1 \times$ $\mathrm{SSC} / 0 \cdot 1 \%(\mathrm{w} / \mathrm{v}$ ) SDS for $15 \mathrm{~min}$ (high stringency) or 5-10 min (low stringency).

DNA fragment nomenclature. Fragments produced by digestion of PSU-1 DNA with a single restriction endonuclease were named by the initial letter of the enzyme (A, AscI; F, FseI; N, NotI; S, SfiI). In the case of DNA from strain GM the superscript GM was added. Fragments resulting from partial digestions were named as above, preceded by the letter P. All fragments were numbered in order, from the largest to the smallest. For co-migrating fragments, sequential numbers were assigned. Fragments that could only be obtained by double digestion were designated using the names of the respective single-digestion overlapping fragments joined by a hyphen.

\section{RESULTS}

\section{Restriction digestion patterns of genomic DNA}

A macrorestriction analysis previously performed on 30 strains of O. oeni (Tenreiro et al., 1994) showed that AscI, NotI and SfiI, generating an average number of fragments between 4 and 17, were suitable enzymes for physical mapping. In strain PSU-1 these enzymes cleaved the chromosome into 4,12 and 16 restriction fragments, respectively (the 12th NotI fragment, of $6 \mathrm{~kb}$, had not been previously detected). Two other $8 \mathrm{bp}$ specific enzymes, FseI and $\mathrm{Srfl}$, generated 8 and 9 fragments when tested on this strain. As Srfl profiles were usually interspersed with partial digestion fragments, only FseI was further retained. The estimated mean sizes of the fragments produced by each enzyme are listed in Table 2 and the restriction profiles are shown in the PFGE photographs. Fragments ranged from 6 to $990 \mathrm{~kb}$ and were resolvable under the PFGE conditions described, except for one NotI (N8/N9) and two SfiI bands (S11/S12 and S13/S14) that were assumed to be doublets. The genome size of O. oeni PSU-1 was determined to be $1857 \mathrm{~kb}$, the mean of the sizes obtained with the four enzymes.

Electrophoretic mobility of macrorestriction fragments was always dependent on run pulse time, indicating that neither of the fragments corresponded to circular molecules (Beverly, 1988; Smith \& Condemine, 1990). On the other hand, no signal was obtained in Southern 
blots using oenophage DNAs as hybridization probes (Santos, 1995; Santos et al., 1996). Therefore, no plasmids and prophages that could contribute to the cleavage patterns were found in strain PSU-1.

\section{Ascl cleavage map of the 0 . oeni PSU-1 genome}

Partial digestions with Ascl were performed to determine the order of the four AscI fragments. As shown in Fig. 1, six partial fragments were obtained, PA1 to PA6, with approximate sizes of $1870,1350,1125,860$, 730 and $350 \mathrm{~kb}$, respectively. Partial fragments PA3, PA5 and PA6 were interpreted as A1 plus A4, A2 plus A3 and $A 3$ plus $A 4$, respectively, whereas the PA2 and PA4 products should correspond to the linkages A3-A4-A1 and A2-A3-A4. The largest partial fragment, PA1, had an estimated size equivalent to the linearized chromosome. According to these data, the four AscI fragments were ordered as A1-A2-A3-A4 and the circular topology of the chromosome was confirmed.

\section{Alignment of Notl fragments}

Comparison of double and sequential digests (2D-PFGE) with single AscI and NotI profiles allowed the positioning of three NotI sites in the AscI physical map and the allocation of all NotI fragments to the corresponding AscI fragments, except for N12. Since fragments N1, N2 and N9 disappeared in the AscI-NotI double digestion (Fig. 2), the AscI sites were assigned to them (see physical map in Fig. 5). As shown in Table 3 and partially in Fig. 2, fragments N3, N4, N8 and N11 could be allocated to A1 and fragments N5, N6, N7 and N10 to A2. Owing to its small size ( $6 \mathrm{~kb}), \mathrm{N} 12$ could only be assigned to fragment A1 by hybridization (Table 4).

From the results of sequential digestion (Table 3) it was possible to deduce the clockwise linkage N2-N1. The corresponding junction site could be located in the AscI map, since A3 was cleaved by NotI into two fragments, A3-N1 and A3-N2, of $153 \mathrm{~kb}$ and $67 \mathrm{~kb}$, respectively. As two linking clones, lc-4 and lc-36 (Table 4), identified the linkages N2-N5 and N5-N6, the clockwise linkage N6-N5-N2-N1 was also deduced.

To identify other linkages between NotI bands, macrorestriction fragments obtained with this enzyme from a strain with a different profile (Tenreiro et al., 1994), O. oeni GM, were used as probes. Hybridization with fragment $\mathrm{N} 1{ }^{\mathrm{GM}}(690 \mathrm{~kb})$ indicated that $\mathrm{N} 3$ is adjacent to $\mathrm{N} 1$, whereas a composite probe containing fragments $\mathrm{N} 8^{\mathrm{GM}}$ and $\mathrm{N} 9^{\mathrm{GM}}$ (both $63 \mathrm{~kb}$ ) hybridized with five Not $\mathrm{I}$ (N1, N2, N3, N8 and N11) and three AscI (A1, A2 and A3) PSU-1 fragments (Table 4). As linkages N1-N2 and N1-N3 have been established, targets of this composite probe should be localized far apart and separated by a large portion of N1. Thus, one of them must hybridize with N2-N1 and A2-A3, and the other with $\mathrm{A} 1$ and N3, N8 and N11. The hybridization signal observed for PSU1 fragment N8 (44 kb) was stronger than those observed for N3 and N11, suggesting the N3-N8-N11 linkage.

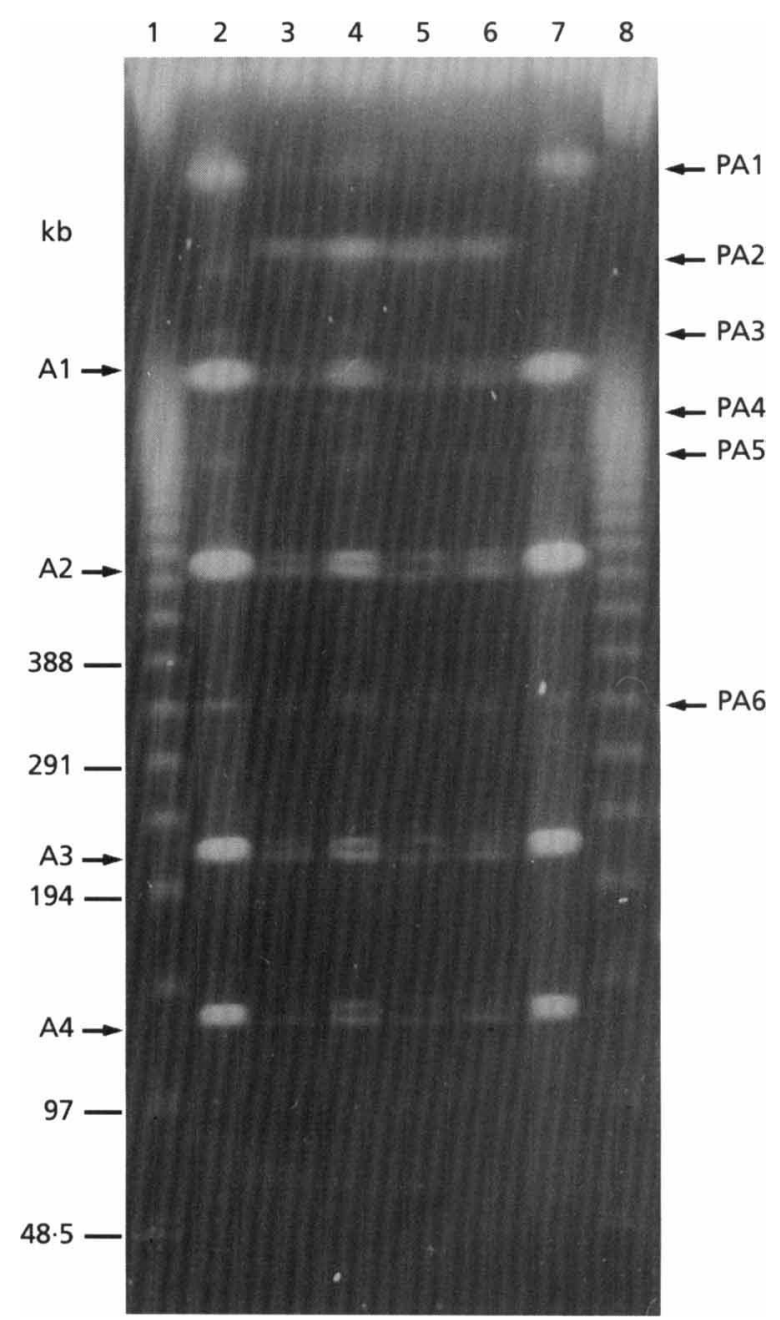

Fig. 1. Ascl partial digestion fragments of the 0 . oeni PSU-1 chromosome separated by PFGE. Lanes 1 and 8, lambda DNA PFG ladder; lanes 2-7, PSU-1 DNA cleaved by Ascl using $2 \mathrm{U}$ overnight (lane 2), $5 \mathrm{U}$ for $1 \mathrm{~h}$ (lane 3), $5 \mathrm{U}$ for $2 \mathrm{~h}$ (lane 4), $10 \mathrm{U}$ for $30 \mathrm{~min}$ (lane 5), $10 \mathrm{U}$ for $1 \mathrm{~h}$ (lane 6), $10 \mathrm{U}$ overnight (lane 7). running conditions: pulse time ramped from 5 to $120 \mathrm{~s}$ over $22 \mathrm{~h}$ at $210 \mathrm{~V}(5-10 \mathrm{~s} / 5 \mathrm{~h} ; 10-30 \mathrm{~s} / 6 \mathrm{~h} ; 30-60 \mathrm{~s} / 4 \mathrm{~h} ; 60-80 \mathrm{~s} / 4 \mathrm{~h}$; $80-120 \mathrm{~s} / 3 \mathrm{~h}) ; 1 \%(\mathrm{w} / \mathrm{v})$ SeaKem GTG agarose (FMC) in $0.5 \times$ TBE; CHEF system (Gene Navigator). Bands of complete and partial digestion are referred to as described in Methods.

Since fragments N7 and N10 were located in A2 (Table 3 ), they must be positioned between N9 and N6, although their relative order could not be ascertained. Altogether, the clockwise linkage N9-(N7,N10)-N6-N5N2-N1-N3-N8-N11 was deduced.

Cross-hybridization with fragments $\mathrm{N} 4^{\mathrm{GM}}$ and $\mathrm{N} 10^{\mathrm{GM}}$ revealed that the first probe hybridized with N4, S2 and S6, whereas the second hybridized with N9, S6 and S1 (Table 4). As the linkage S2-S6-S1 was established from Sfil physical mapping (see below) and PSU-1 fragment N12 hybridized with S2 (Table 4), the clockwise order of NotI fragments N1-N3-N8-N11-N12-N4-N9-(N7, N10)-N6-N5-N2 was established, as shown in Fig. 5. 


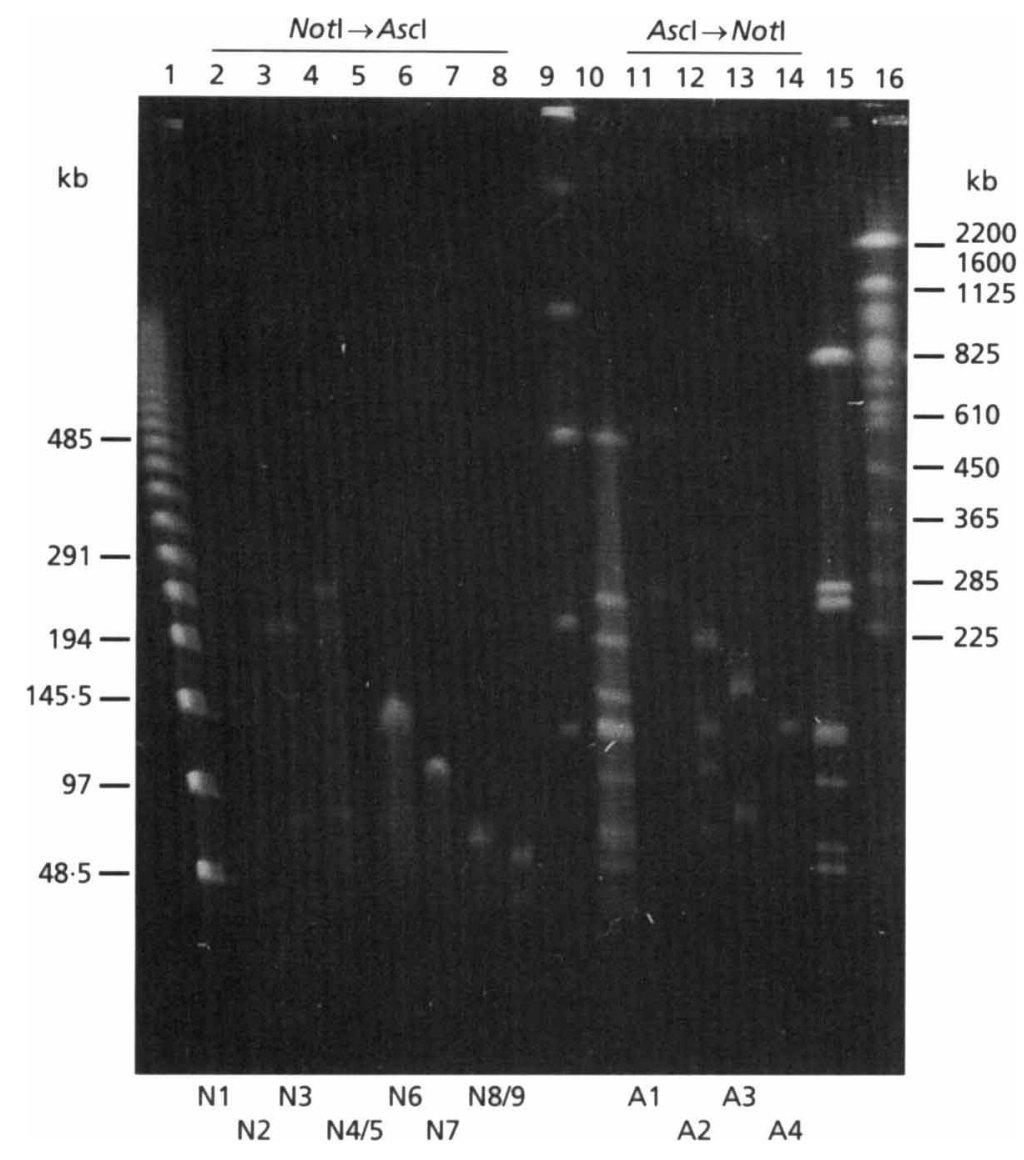

Fig. 2. Two-dimensional PFGE separation of the DNA fragments generated by NotI-Ascl and Ascl-Notl double digestion of $O$. oeni PSU-1 DNA. Migration parameters were identical to those described in Fig. 1. Lane 1, lambda DNA PFG ladder; lanes 2-8, Notl fragments isolated from the first dimension and digested with Ascl; lane 9, Ascl-digested genomic DNA; lane 10, Ascl-Notl doubledigested genomic DNA; lanes 11-14, Ascl fragments isolated from the first dimension and digested with Notl; lane 15, Notldigested genomic DNA; lane 16, Saccharomyces cerevisiae chromosomes. The letters under the lanes refer to the fragments (described in Table 2) produced by the endonuclease used in the first digestion.

\section{Alignment of Sfi fragments}

The analysis of double and sequential digestions with AscI, NotI and SfiI (Fig. 3, Table 3) made possible the allocation of $S f i$ fragments to the AscI and NotI physical map, except for S13, S15 and S16. As fragments S3 and S8 were cleaved by AscI and partially contained in A3, two AscI sites were assigned to these fragments and the linkage S8-S3 was deduced. The position in the AscI map of the Sfil site between these fragments was obtained from the estimated sizes of double-digestion fragments, A3-S3 (146 kb) and A3-S8 (74 kb). The other two AscI sites were located in $\mathrm{S} 12$ and $\mathrm{S} 6$ by crosshybridization with fragments $\mathrm{N} 2^{\mathrm{GM}}$ and $\mathrm{N} 10^{\mathrm{GM}}$ (Table 4), which also made evident the linkages S8-S3-S12-S5 and S6-S1. Assignment of fragments S9, S11 and S14 to $\mathrm{A} 2-\mathrm{N} 2$, fragments $\mathrm{S} 4, \mathrm{~S} 7$ and $\mathrm{S} 10$ to $\mathrm{A} 1-\mathrm{N} 1$, and fragment S2 to N3, was sustained both by AscI-SfiI and NotI-SfiI double and sequential digestions.

Using fragments S15 and S16 as probes, their positions were assigned to N3 and A2-N2, respectively (Table 4). As fragment S13 was cleaved by NotI and fragment $\mathrm{N} 1^{\mathrm{GM}}$ hybridized with S13, N1 and N3, fragment S13 must contain the NotI site between $\mathrm{N} 1$ and N3. The clockwise linkage S6-S1-(S9, S11, S14, S16)-S8-S3-S12S5-(S4, S7, S10)-S13-S15-S2 was thus deduced.

Cross-hybridization with fragment $\mathrm{N} 4^{\mathrm{GM}}$ confirmed the linkage S2-S6, whereas probes $\mathrm{S} 6^{\mathrm{GM}}$ and $\mathrm{S} 17^{\mathrm{GM}}$ confirmed the location of fragments S7 and S10 in N1.
Taking into account that the linkages S1-S11 and S5-S4 were obtained from composite probe $\mathrm{S} 1^{\mathrm{GM}} / \mathrm{S} 2^{\mathrm{GM}}$ (Table 4), a further alignment of $S$ fil fragments was performed, leading to the linkage S8-S3-S12-S5-S4-(S7, S10)-S13S15-S2-S6-S1-S11-(S9, S14, S16).

As shown in Fig. 3 and Table 4, the rrs probe hybridized with fragments S2 and S14 and FseI fragments F1, F3 and F5. Associated with the FseI map described below, these results led to the SfiI physical map presented in Fig. 5. In this map, the relative order of fragments S7 and S10 remains unknown, as does the exact position of fragment S16. Nevertheless, this fragment must be located in the region between S11 and S8 (Fig. 5) because it hybridizes with N2 (Table 4).

\section{Alignment of Fsel fragments and physical map of $\boldsymbol{O}$. oeni PSU-1}

Analysis of the FseI-NotI double digestion (see Fig. 4) showed that fragments F1, F2 and F3 disappeared as well as $\mathrm{N} 1, \mathrm{~N} 2$ and $\mathrm{N} 3$, allocating all the restriction sites of both enzymes to these fragments. From results of cross-hybridization with fragments A4 (Fig. 4b, Table 4) and S11/S12 (Table 4), the clockwise linkage F6-F4 was established and fragments S11 and S12 were assigned to $\mathrm{F} 1$ and $\mathrm{F} 4$, respectively. Using fragment $\mathrm{N} 1^{\mathrm{GM}}$ as probe (Table 4), the linkage F6-F4-(F2, F5, F8)-F1 was deduced. When $r r s$ was used as probe, hybridization signals were obtained in F1, F3 and F5 (Table 4), revealing that F1 
Table 3. Ascl, Notl and Sfil double restriction fragments of 0 . oeni PSU-1 chromosome

\begin{tabular}{|c|c|c|}
\hline $\begin{array}{l}\text { First } \\
\text { enzyme }\end{array}$ & Fragment ${ }^{*}$ & Products after digestion with the second enzyme \\
\hline AscI & $\begin{array}{l}\text { A1 } \\
\text { A2 } \\
\text { A4 }\end{array}$ & 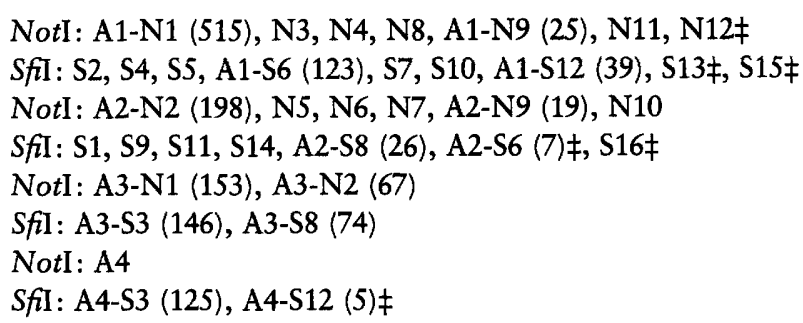 \\
\hline NotI & $\begin{array}{l}\text { N1 } \\
\text { N2 } \\
\text { N3 } \\
\text { N4 } \\
\text { N5 } \\
\text { N6 } \\
\text { N7 } \\
\text { N8 } \\
\text { N9 } \\
\text { (N10) } \\
\text { (N11) } \\
\text { (N12) }\end{array}$ & 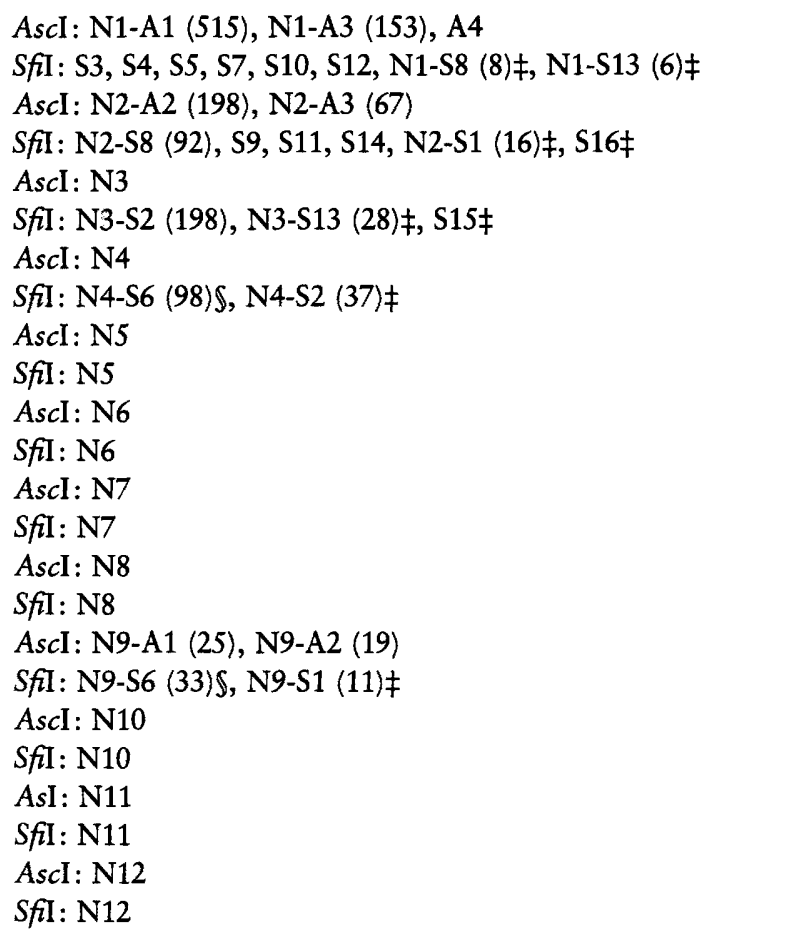 \\
\hline SfiI & $\begin{array}{l}\mathrm{S} 1 \\
\mathrm{~S} 2 \\
\mathrm{~S} 3 \\
\mathrm{~S} 4 \\
\mathrm{~S} 5 \\
\mathrm{~S} 6 \\
\mathrm{~S} 7 \\
\mathrm{~S} 8 \\
\mathrm{~S} 9 \\
\mathrm{~S} 10 \\
(\mathrm{~S} 11)\end{array}$ & 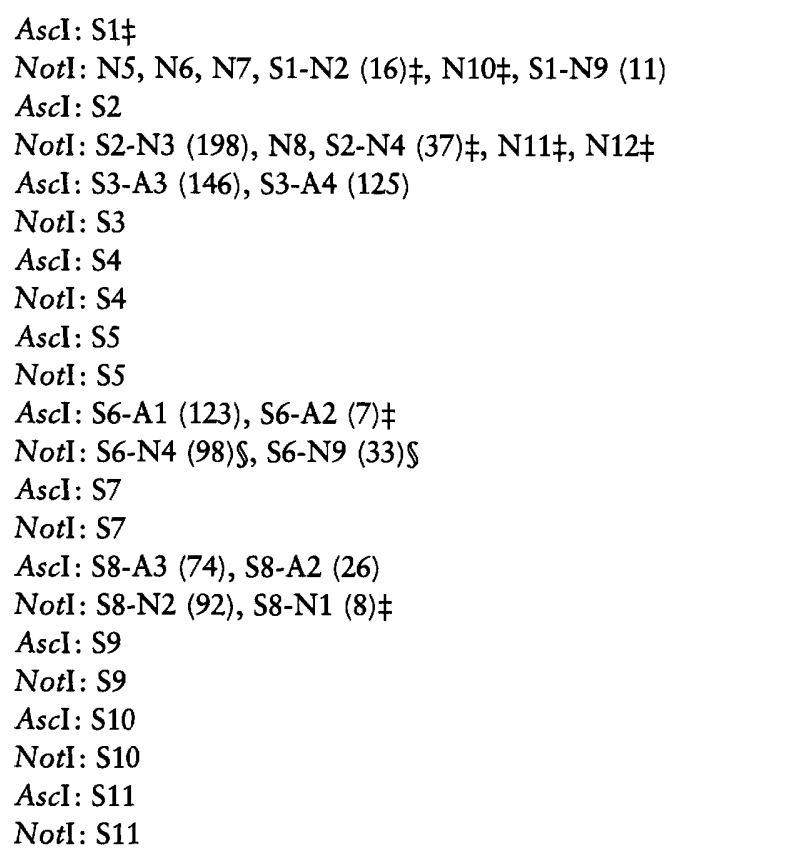 \\
\hline
\end{tabular}


Table 3. (cont.)

\begin{tabular}{|c|c|c|}
\hline $\begin{array}{l}\text { First } \\
\text { enzyme }\end{array}$ & Fragment ${ }^{*}$ & Products after digestion with the second enzyme $\dagger$ \\
\hline & $\begin{array}{l}(\mathrm{S} 12) \\
(\mathrm{S} 13) \\
(\mathrm{S} 14) \\
(\mathrm{S} 15) \\
(\mathrm{S} 16)\end{array}$ & $\begin{array}{l}\text { AscI : S12-A1 (39), S12-A4 (5) } \\
\text { NotI: S12 } \\
\text { AscI: S13 } \\
\text { NotI: S13-N3 (28), S13-N1 (6) } \\
\text { AscI: S14 } \\
\text { NotI: S14 } \\
\text { AscI: S15 } \\
\text { NotI: S15 } \\
\text { AscI: S16 } \\
\text { NotI: S16 }\end{array}$ \\
\hline
\end{tabular}

* Fragment sizes are presented in Table 2. Cleavage products from fragments in parentheses were deduced from double digestions in one-dimensional PFGE. Otherwise, separation of products from the second digestion was performed by two-dimensional PFGE.

$\dagger$ Numbers in parentheses refer to theoretical sizes in $\mathrm{kb}$ obtained after location of restriction sites on the physical map.

$\ddagger$ Fragments not observed in sequential digests (2D PFGE).

$\$$ Fragments observed in double and/or sequential digests that were assigned to the second enzyme only after hybridization.

linked F3 with F5. A hybridization signal with this gene probe was also observed in a partial digestion fragment smaller than F2 (approximately $320 \mathrm{~kb}$; data not shown), suggesting the linkage of $F 7(75 \mathrm{~kb})$ to $F 3$ $(240 \mathrm{~kb})$. This probe further hybridized to the doubledigestion fragment A2-F3 (120 kb; data not shown) providing the necessary information to locate the F1-F3 joining site in the AscI physical map.

The last piece of the puzzle came from the double digestion FseI-SfiI. In fact, S4 and S5 were both cleaved with FseI (Fig. 4), allocating F8 to the linkage S4-S5 and indicating the clockwise order F4-F8-F2-F5-F1-F3-F7F6.

The physical map of the PSU-1 chromosome obtained with the four enzymes referred to above is shown in Fig. 5 . The observed sizes of the restriction fragments were corrected to map sizes (Table 2), to agree with all the data from hybridization and double and sequential digestions.

Analysis of macrorestriction sites on the PSU-1 genome showed that map intervals, defined by two consecutive sites, varied between $5 \mathrm{~kb}$ (F5-S13) and $151 \mathrm{~kb}$ (F2-S4).

\section{Mapping of genetic markers in the PSU-1 chromosome}

The probes described in Table 1 were used to locate six homologous and four heterologous genes on the physical map of the O. oeni PSU-1 genome (Fig. 5). The probes have been assigned to the restriction fragments to which they hybridized (Table 4), although their exact positioning on the fragment is unknown. For probes that hybridized with the same fragment the relative posi- tioning was arbitrary, not reflecting their real order in the chromosome. Only $r r n$ gene probes were hybridized with FseI-digested DNA.

(i) rrn operons. O. oeni strains contain two $r r n$ operons on their chromosome, with the typical $5^{\prime}-r r s-r r l-r r f-3^{\prime}$ organization found in the majority of bacteria (Zavaleta et al., 1996). According to the physical map (Fig. 5) and the hybridization results obtained with $r r s$ and $r r l$ probes on PSU-1 DNA digested with AscI, NotI or Sfil (Table 4), the two operons must be located in fragments S2-N3 and S14, which are at least $600 \mathrm{~kb}$ apart. When the rrs published sequence (Martinez-Murcia \& Collins, 1990) was screened for the presence of restriction sites, one Fse I cutting site was found at position 324, allowing a more precise location of $r r n$ genes. In addition, hybridization results obtained on FseI digests revealed three positive fragments with the rrs probe (F1, F3 and F5) and only one with the $r r l$ probe (F1), showing that $r r s$ genes are $692 \mathrm{~kb}$ apart and that the operons have opposite orientation in the PSU-1 chromosome, with $r r n A$ transcribed clockwise and $r r n B$ counterclockwise (Fig. 5).

(ii) Oenococcal genes. The mleA gene, which encodes the malolactic enzyme and belongs to the mle locus (Labarre et al., 1996), and the alsS/alsD genes, encoding $\alpha$ acetolactate synthase and decarboxylase (Garmyn et al., 1996), were located in fragments S7 and S4 respectively.

A fragment of PSU-1 DNA cloned in pMK4 (Sulivan et al., 1984) and conferring mitomycin $C$ resistance upon a recA E. coli strain was obtained in our laboratory (Brito, 1996). The locus responsible for this phenotype (mir, for mitomycin resistance) was located in fragment N7 (Fig. 5).

(iii) Heterologous genes. Since very few genes of O. oeni 
Table 4. Assignment of hybridization probes to restriction fragments of 0 . oeni PSU-1 chromosome

\begin{tabular}{|c|c|c|c|c|}
\hline \multirow{2}{*}{$\begin{array}{l}\text { Fragment or } \\
\text { marker used } \\
\text { as probe }\end{array}$} & \multicolumn{4}{|c|}{ Hybridizing fragment(s) } \\
\hline & AscI & FseI & NotI & SfiI \\
\hline \multicolumn{5}{|c|}{ Genetic markers } \\
\hline rrs & $\mathrm{A} 1, \mathrm{~A} 2$ & F1, F3, F5 & $\mathrm{N} 2, \mathrm{~N} 3$ & S2, S14 \\
\hline$r r l$ & $\mathrm{~A} 1, \mathrm{~A} 2$ & $\mathrm{~F} 1$ & $\mathrm{~N} 2, \mathrm{~N} 3$ & S2, S14 \\
\hline $\operatorname{mir}$ & A1 & NT & N7 & S1 \\
\hline mleA & A1 & NT & N1 & S7 \\
\hline alsS/alsD & A1 & NT & N1 & S4 \\
\hline $\operatorname{rec} A$ & A1 & NT & N3 & S2 \\
\hline IS 1165 & $\mathrm{~A} 1, \mathrm{~A} 2$ & NT & $\mathrm{N} 1, \mathrm{~N} 2, \mathrm{~N} 3$ & S1, S2, S4, S8 \\
\hline citP & A3 & NT & $\mathrm{N} 1$ & S8 \\
\hline $\operatorname{araA}$ & A4 & NT & $\mathrm{N} 1$ & S3 \\
\hline \multicolumn{5}{|c|}{ Other markers* } \\
\hline attB1 & A3 & F3 & $\mathrm{N} 2$ & S8 \\
\hline attB2 & $\mathrm{A} 2$ & F1 & N2 & S11 \\
\hline lc-4 & A2 & NT & N5, N6 & S1 \\
\hline lc-36 & A2 & NT & $\mathrm{N} 2, \mathrm{~N} 5$ & S1 \\
\hline \multicolumn{5}{|c|}{ PSU-1 DNA fragments } \\
\hline A3 & A3 & NT & $\mathrm{N} 1, \mathrm{~N} 2$ & S3, S8 \\
\hline A4 & A4 & $\mathrm{F} 4, \mathrm{~F} 6$ & N1 & S3 \\
\hline $\mathrm{N} 4 / 5$ & $\mathrm{~A} 1, \mathrm{~A} 2$ & NT & N4, N5 & S1, S2, S6 \\
\hline N11 & $\mathrm{A} 1$ & F1 & N11 & S2 \\
\hline N12 & A1 & NT & N12 & S2 \\
\hline $\mathrm{S} 11 / \mathrm{S} 12$ & $\mathrm{~A} 1, \mathrm{~A} 2$ & F1, F4 & $\mathrm{N} 1, \mathrm{~N} 2$ & $\mathrm{~S} 11, \mathrm{~S} 12$ \\
\hline S15 & A1 & NT & N3 & S15 \\
\hline$S 16$ & A2 & NT & N2 & S16 \\
\hline \multicolumn{5}{|c|}{ GM DNA fragments } \\
\hline $\mathrm{N} 1$ & $\mathrm{~A} 1$ & $\begin{array}{c}\text { F1, F2, F4, } \\
\text { F5, F8 }\end{array}$ & $\mathrm{N} 1, \mathrm{~N} 3$ & $\begin{array}{r}\text { S2, S4, S5, S7, } \\
\text { S10, S13, S15 }\end{array}$ \\
\hline $\mathrm{N} 2$ & $\mathrm{~A} 1, \mathrm{~A} 3, \mathrm{~A} 4$ & NT & N1 & S3, S5, S12 \\
\hline $\mathrm{N} 4$ & $\mathrm{~A} 1$ & NT & N4 & S2, S6 \\
\hline N5 & A2 & NT & N5 & S1 \\
\hline $\mathrm{N} 8 / \mathrm{N9}$ & $\mathrm{A} 1, \mathrm{~A} 2, \mathrm{~A} 3$ & NT & $\begin{array}{c}\mathrm{N} 1, \mathrm{~N} 2, \mathrm{~N} 3, \mathrm{~N} 8, \\
\mathrm{~N} 11\end{array}$ & $\mathrm{~S} 2, \mathrm{~S} 3, \mathrm{~S} 8$ \\
\hline N10 & $\mathrm{A} 1, \mathrm{~A} 2$ & NT & N9 & $\mathrm{S} 1, \mathrm{~S} 6$ \\
\hline N11 & $\mathrm{A} 1$ & NT & N1 & S5 \\
\hline S1/S2 & $\mathrm{A} 1, \mathrm{~A} 2$ & NT & $\begin{array}{c}\text { N1, N2, N5, N6, } \\
\text { N7, N9, N10 }\end{array}$ & $\begin{array}{c}\text { S1, S4, S5, S11, } \\
\text { S12 }\end{array}$ \\
\hline S6 & A1 & F2 & N1 & S7 \\
\hline S15 & A2 & NT & N2 & S14 \\
\hline S17 & A1 & F2 & N1 & S10 \\
\hline $\mathrm{S} 18$ & $\mathrm{~A} 1, \mathrm{~A} 4$ & NT & N1 & $\mathrm{S} 12$ \\
\hline
\end{tabular}

NT, Not tested.

* attB1 and attB2 refer to attachment sites of phage fOg44 and were localized on AscI, NotI and SfiI fragments by hybridization of phage DNA to lysogenic derivatives of strain PSU-1 (Santos, 1995; Santos et al., 1996). Assignment to Fsel fragments resulted from size shifting analysis as described. lc-4 and lc36 represent NotI linking clones.

have been described, gene probes from other Grampositive bacteria with low $\mathrm{G}+\mathrm{C}$ content were used under low-stringency hybridization conditions (Table 1). The map location of these genes is also presented in Fig. 5. (iv) Phage attachment sites. Although PSU-1 is a phagefree strain, lysogenic derivatives have been constructed (Santos et al., 1996). Two attachment sites for phage fOg44 (attB1 and attB2) were previously assigned to AscI, NotI and SfiI macrorestriction fragments (Santos, 
(a)

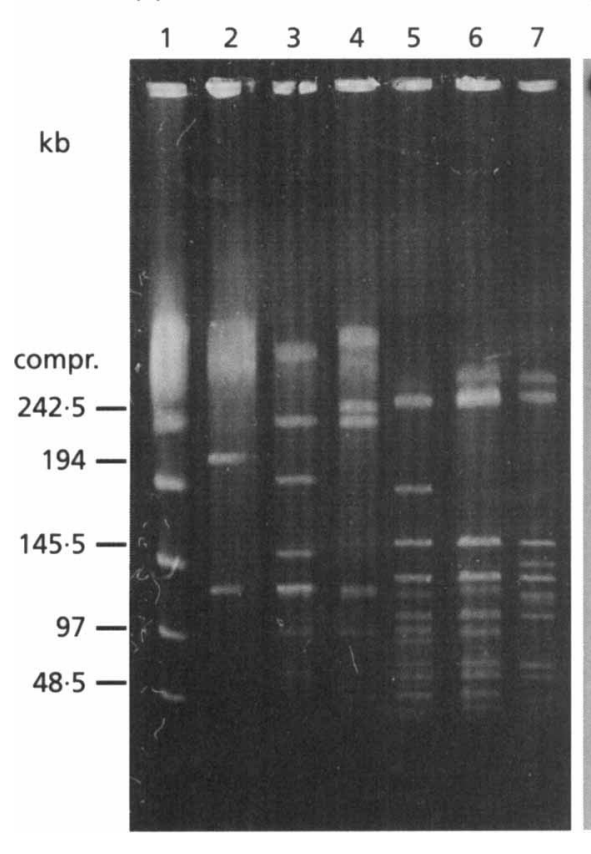

(b)

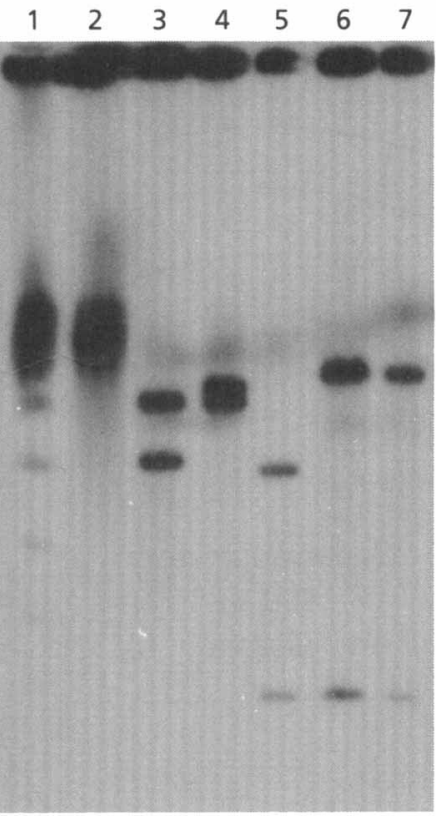

Fig. 3. (a) Single and double digestion profiles of 0 . oeni PSU-1 chromosomal DNA obtained with Ascl, Notl and Sfil. Lane 1, lambda DNA PFG ladder; lane 2, Ascl; lane 3. Ascl-Notl; lane 4, Notl; lane 5, Notl-Sfil; lane 6, Sfil; lane 7, Sfil-Ascl. Running conditions: pulse time from 1 to $9 \mathrm{~s}$ at $180 \mathrm{~mA}$ for $5 \mathrm{~h}$, followed by $10-30 \mathrm{~s}$ at $90 \mathrm{~mA}$ for $15 \mathrm{~h} ; 1 \%$ (w/v) SeaKem LE agarose (FMC) in $1 \times$ TAE; TAFE system (Geneline). compr., compression zone for DNA. (b) Southern blot of gel in (a) hybridized with rrs probe from 0 . oeni L217'. (a)

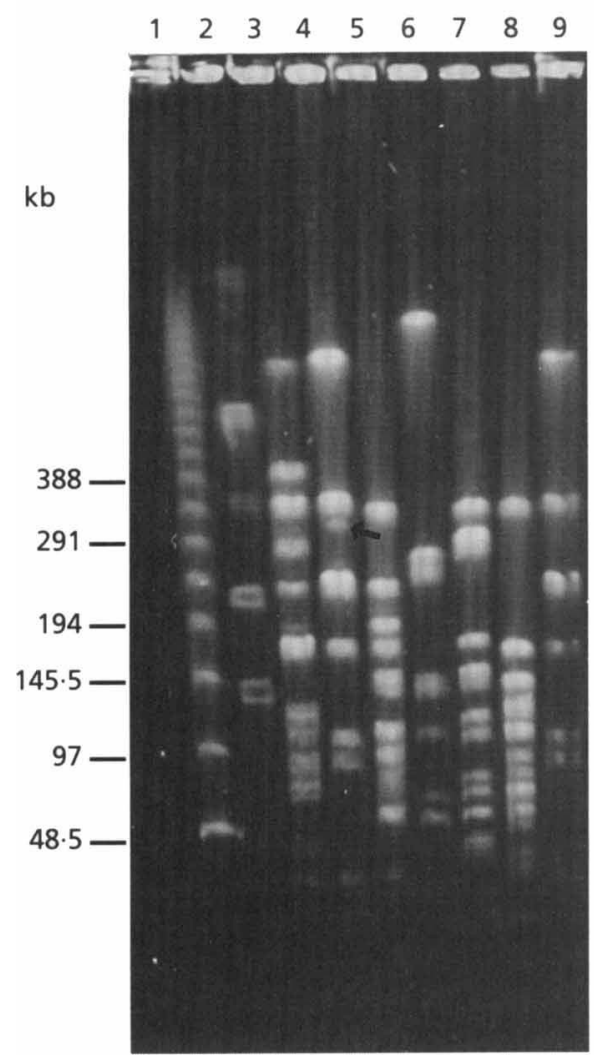

(b)

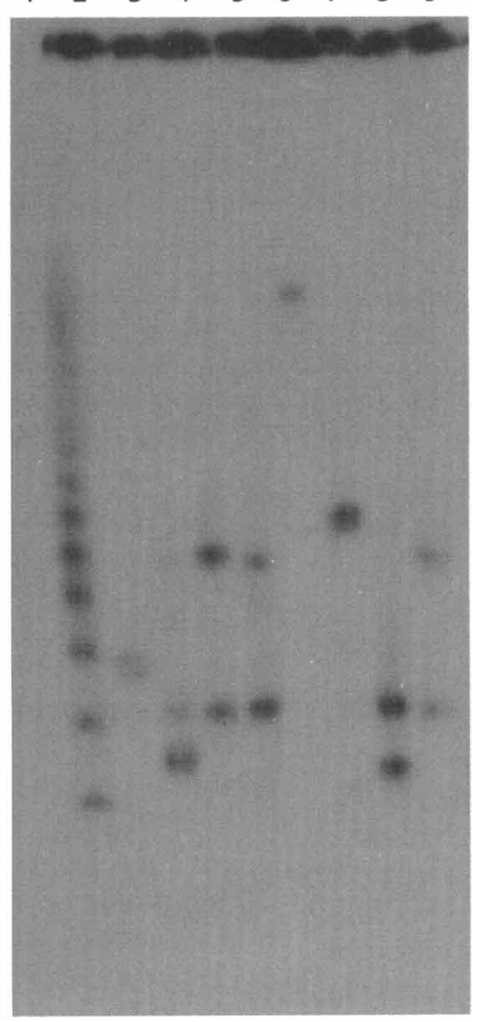

Fig. 4. (a) Fsel single and double restriction profiles of O. oeni PSU-1 chromosomal DNA. Migration parameters were identical to those described in Fig. 1. Lane 1, lambda DNA PFG ladder; lane 2, Ascl; lane 3, FselAscl; lane 4, Fsel (partial fragment F3-F7 is shown by an arrow); lane 5, Fsel-Notl; lane 6, Notl; lane 7, Sfil; lane 8, Fsel-Sfil; lane 9, Fsel. (b) Southern hybridization of gel in panel (a) using fragment A4 from $O$. oeni PSU-1 as probe.
1995; Santos et al., 1996). These results have been confirmed in the present study (Table 4), which extended the localization of $a t t B 1$ and $a t t B 2$ to the FseI map. In fact, a $40 \mathrm{~kb}$ size increase (corresponding to the phage genome size; Santos et al., 1996) was observed in fragment F3 for a single lysogen, whereas both F3 and F1 increased by this amount in a double lysogen (data not shown). The position of the phage attachment sites in these FseI fragments is in agreement with mapping results described above. 


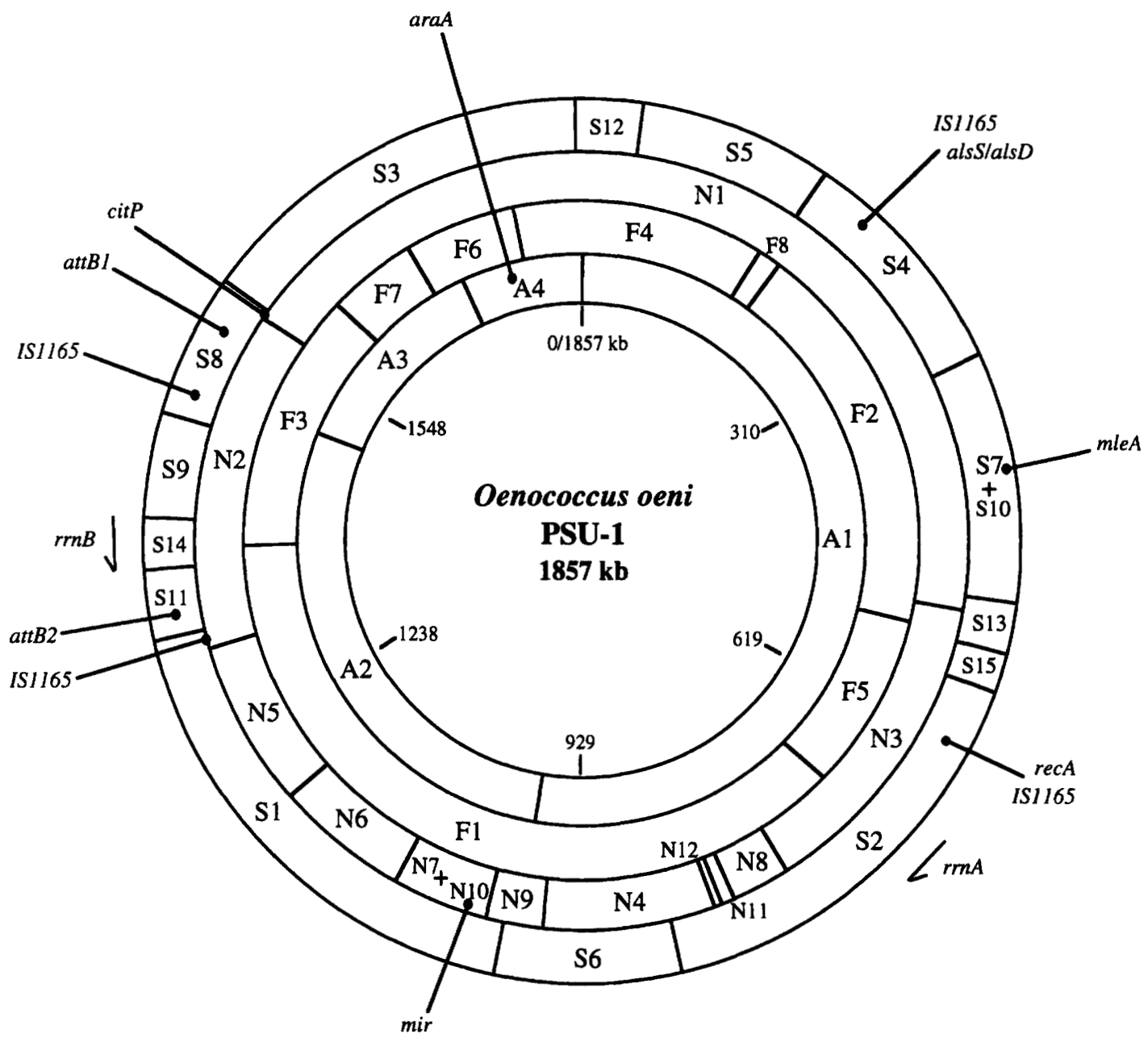

Fig. 5. Physical map of the chromosome of $O$. oeni PSU-1 using the enzymes Ascl, Fsel, Notl and Sfil. Radiating out from the centre, the four annuli show the restriction sites for the four respective enzymes. Restriction fragments are identified as shown in Table 2; the scale is in kb. Fragments N7 and N10 could not be oriented, nor could S7 and S10. Fragment S16 is not shown on the map as its position was not assessed with precision. The locations of several genetic markers are also shown, although the order of markers in a single fragment is arbritrary. Direction of transcription of rrn operons is indicated by an arrow.

\section{DISCUSSION}

A physical map of the genome of $O$. oeni PSU-1 has been constructed using rare-cutting enzymes, PFGE and hybridization techniques. To our knowledge this is the first genome restriction map of a strain of this species. The chromosome of O. oeni PSU-1 was shown to be circular, as described for the majority of known bacterial genomes (Cole \& Saint-Girons, 1994; Krawieck \& Riley, 1990), with an estimated size of $1857 \mathrm{~kb}$. This value is in close agreement with previous determinations (Tenreiro et al., 1994), although size corrections smaller than $4 \%$ were applied to some restriction fragments over $130 \mathrm{~kb}$ to integrate all the data in a coherent map.

This genome size is at the lower extreme of the range described for lactic acid bacteria $(3.4-1.75 \mathrm{Mb}$, as reviewed by Davidson $e t$ al., 1996). Such a small genome could reflect the huge requirement for growth factors and the limited biochemical complexity of these Gram- positive bacteria (Le Bourgeois et al., 1993; Tulloch et al., 1991), as well as the specific adaptation to an almost non-fluctuating ecosystem (Roussel et al., 1994).

Four restriction endonucleases, AscI, FseI, NotI and SfiI, recognizing eight GC-pair sequences, were employed and 37 restriction sites were mapped using several experimental approaches. Analysis of partial digestion products led to the complete AscI physical map, whereas the majority of NotI and Sfil fragments have been assigned to the overlapping AscI fragments by twodimensional PFGE. To improve the visualization and assignment of fragments resulting from the secondary cleavage, which are sometimes hindered by the punctiform appearance of these fragments with the 2D techniques commonly used (Bautsch, 1988; Davidson et al., 1992; Tulloch et al., 1991), bands from the first dimension were individually excised and digested, rather than being collectively processed in a single agarose slice (see Methods). Mapping of NotI, SfiI and FseI sites was 
achieved mostly by hybridization, by using either linking clones or fragments generated by a different enzyme. The use of random-labelled macrorestriction fragments from a different $O$. oeni strain proved to be a useful additional hybridization strategy owing to the different positioning of restriction sites in the two strains. The occurrence of rearrangements such as inversions of large genomic segments, which could lead in these experiments to wrong assumptions concerning fragment linkage, has been ruled out by the observed internal consistency with data obtained from other approaches. A globally similar genetic organization in O. oeni strains exhibiting fragment length polymorphisms is not unexpected, as several lines of evidence have highlighted the homogeneous nature of this species (Zavaleta et al., 1996, 1997).

Although similar-sized fragments were observed with both NotI and SfiI, their allocation was not difficult since at least one enzyme cleaved only one fragment of the doublet. Three restriction sites could not be precisely positioned on the physical map. Nevertheless, one leads to an Sfil fragment of $6 \mathrm{~kb}$ with three possible positions in an approximately $160 \mathrm{~kb}$ region of the PSU-1 chromosome, whereas alternative positions less than $50 \mathrm{~kb}$ apart were assigned for the remaining two.

The localization of 10 genetic markers on the physical map represents a first step towards the construction of a genetic map of the $\mathrm{O}$. oeni chromosome. Homologous markers included the genes for malolactic enzyme $(m l e A), \alpha$-acetolactate synthase $(a l s S)$ and $\alpha$-acetolactate decarboxylase $(a l s D)$, formerly described in another strain of this species (Garmyn et al., 1996; Labarre et al., 1996), and a cloned fragment of PSU-1 DNA conferring resistance to mitomycin C in E. coli (mir). The two rrn operons reported in the O. oeni genome (Zavaleta et al., 1996) were also mapped by using homologous $r r s$ and $r r l$ probes. As gene organization follows the typical $r r s-r r l-$ $r r f$ pattern and FseI cleaves the $r r s$ sequence of O. oeni at a unique site, an accurate positioning and orientation of $r r n$ operons was obtained, with $r r n A$ transcribed clockwise and $r r n B$ counterclockwise. Assuming that chromosome replication and $r r n$ transcription are processed in the same direction as generally found (Davidson $e t$ al., 1996; Krawieck \& Riley, 1990), the origin of replication in $O$. oeni is probably located in the larger region separating the two operons.

Since very few genes of $O$. oeni have been studied, probes from other low-G $+C$ Gram-positive bacteria were used under low-stringency conditions, to minimize the effects of DNA sequence divergence. These heterologous genes (recA, citP and araA) allowed the identification of PSU-1 DNA sequences which may have a similar coding function. Although no definite assumption can be made in this regard, it is worth noting that the relatively conserved nature of $r e c A$ from different species has been established (Eisen, 1995), and the PSU1 strain in our collection is able to transport citrate and grow on arabinose (unpublished data).

According to a previous report of IS1165 or related elements in strains of O. oeni (Johansen \& Kibenich, 1992), we found that four segments in the PSU-1 genome hybridized with the IS1165 probe. The phage attachment sites $a t t B 1$ and $a t t B 2$ previously identified in strain PSU1 (Santos et al., 1996) were mapped in this work in a $265 \mathrm{~kb}$ region which also contains $r r n B$ and two putative IS1165 elements.

The physical map of strain PSU-1 reported here has a good resolution for positioning genes, since the majority of the map intervals $(62.5 \%)$ are smaller than $50 \mathrm{~kb}$ and only six fall within $100-200 \mathrm{~kb}$, the minimum acceptable range (Cole \& Saint-Girons, 1994). This distribution of restriction sites clearly represents an advantage for the construction of ordered libraries that will be extremely useful for the genomic characterization of this organism by gene sequencing.

\section{ACKNOWLEDGEMENTS}

We express our gratitude to P. Duwat (Institut National de Recherche Agronomique, Paris, France), J. Guzzo (Laboratoire de Microbiologie, ENSBANA, Dijon, France), P. López (Centro de Investigaciones Biológicas, Madrid, Spain) and I. Sá-Nogueira (Instituto de Tecnologia Química e Biológica, Oeiras, Portugal) for providing gene probes. We are also grateful to Renata Santos for the gift of the lysogenic derivatives of strain PSU-1. We are indebted to Graça Vieira for her encouragement during the study. L.Z. was the recipient of a research grant from PRAXIS XXI (BD/4541/94). This work was partially supported by JNICT grant P/BIC/BIO/$1279 / 92$.

\section{REFERENCES}

Bautsch, W. (1988). Rapid mapping of the Mycoplasma mobile genome by two-dimensional field inversion gel electrophoresis techniques. Nucleic Acids Res 16, 11461-11467.

Beverly, S. M. (1988). Characterization of the 'unusual' mobility of large circular DNAs in pulsed-field gradient electrophoresis. Nucleic Acids Res 16, 925-939.

Brito, L. (1996). Molecular analysis in Leuconostoc oenos. $\mathrm{PhD}$ thesis, Technical University of Lisbon.

Brito, L., Vieira, G., Santos, M. A. \& Paveia, H. (1996). Nucleotide sequence analysis of pOg32, a cryptic plasmid from Leuconostoc oenos. Plasmid 36, 49-54.

Cole, S. T. \& Saint Girons, I. (1994). Bacterial genomics. FEMS Microbiol Rev 14, 139-160.

Davidson, B. E., MacDougall, J. \& Saint Girons, I. (1992). Physical map of the linear chromosome of the bacterium Borrelia burgdorferi 212, a causative agent of Lyme disease, and localization of rRNA genes. J Bacteriol 174, 3766-3774.

Davidson, B. E., Kordias, N., Dobos, M. \& Hillier, A. J. (1996). Genomic organization in lactic acid bacteria. Antonie Leeuwenboek 70, 161-183.

Dicks, L. M. T., Dellaglio, F. \& Collins, M. D. (1995). Proposal to reclassify Leuconostoc oenos as Oenococcus oeni [corrig.] gen. nov., comb. nov. Int J Syst Bacteriol 45, 395-397.

Eisen, J. A. (1995). The RecA protein as a model molecule for molecular systematic studies of bacteria : comparison of trees of RecAs and $16 \mathrm{~S}$ rRNAs from the same species. J Mol Evol 41, 1105-1123.

Fremaux, C., Aigle, M. \& Lonvaud-Funel, A. (1993). Sequence 
analysis of Leuconostoc oenos DNA : organization of pLo13, a cryptic plasmid. Plasmid 30, 212-223.

Garmyn, D., Monnet, C., Martineau, B., Guzzo, J., Cavin, J.-F. \& Diviess, C. (1996). Cloning and sequencing of the gene encoding $\alpha$ acetolactate decarboxylase from Leuconostoc oenos. FEMS Microbiol Lett 145, 445-450.

Garvie, E. (1986). Genus Leuconostoc. In Bergey's Manual of Systematic Bacteriology, pp. 1071-1075. Edited by P. H. A. Sneath, N. S. Mair, M. E. Sharpe \& J. G. Holt. Baltimore: Williams \& Wilkins.

Heath, J. D., Perkins, J. D., Sharma, B. \& Weinstock, G. M. (1992). NotI cleavage map of Escherichia coli K-12 strain MG1655. J Bacteriol 174, 558-567.

Jobin, M.-P., Delmas, F., Garmyn, D., Diviès, C. \& Guzzo, J. (1997). Molecular characterization of the gene encoding a 18-kilodalton small heat shock protein associated with the membrane of Leuconostoc oenos. Appl Environ Microbiol 63, 609-614.

Johansen, E. \& Kibenich, A. (1992). Isolation and characterization of IS1165, an insertion sequence of Leuconostoc mesenteroides subsp. cremoris and other lactic acid bacteria. Plasmid 27, 200-206.

Kelly, W. J., Huang, C. M. \& Asmundson, R. V. (1993). Comparison of Leuconostoc oenos strains by pulsed-field gel electrophoresis. Appl Environ Microbiol 59, 3969-3972.

Krawieck, S. \& Riley, M. (1990). Organization of the bacterial chromosome. Microbiol Rev 54, 502-539.

Kunkee, R. E. (1991). Some roles of malic acid in malolactic fermentation in wine making. FEMS Microbiol Rev 88, 55-72.

Labarre, C., Guzzo, J., Cavin, J.-F. \& Diviès, C. (1996). Cloning and characterization of the genes encoding the malolactic enzyme and the malate permease of Leuconostoc oenos. Appl Environ Microbiol 62, 1274-1282.

Le Bourgeois, P., Lautier, M., Mata, M. \& Ritzenthaler, P. (1992). Physical and genetic map of the chromosome of Lactococcus lactis subsp. lactis IL1403. J Bacteriol 174, 6752-6762.

Le Bourgeois, P., Lautier, M. \& Ritzenthaler, P. (1993). Chromosome mapping in lactic acid bacteria. FEMS Microbiol Rev 12, 109-124.

Martinez-Murcia, A. J. \& Collins, M. D. (1990). A phylogenetic analysis of the genus Leuconostoc based on reverse transcriptase sequencing of 16S rRNA. FEMS Microbiol Lett 70, 73-84.

Martinez-Murcia, A. J., Harland, N. M. \& Collins, M. D. (1993). Phylogenetic analysis of some leuconostocs and related organisms as determined from large-subunit rRNA gene sequences: assessment of congruence of small- and large-subunit rRNA derived trees. J Appl Bacteriol 74, 532-541.

Morse, R., Collins, M. D., O'Hanlon, K., Wallbanks, S. \& Richardson, P. T. (1996). Analysis of the $\beta^{\prime}$ subunit of the DNAdependent RNA polymerase does not support the hypothesis inferred from $16 \mathrm{~S}$ rRNA analysis that Oenococcus oeni (formerly Leuconostoc oenos) is a tachytelic (fast-evolving) bacterium. Int J Syst Bacteriol 46, 1004-1009.

Ohman, D. E. (1988). Experiments in Gene Manipulation. Englewood Cliffs, NJ: Prentice Hall.

Ramos, A. \& Santos, H. (1996). Citrate and sugar cofermentation in Leuconostoc oenos, a ${ }^{13} \mathrm{C}$ nuclear magnetic resonance study. Appl Environ Microbiol 62, 2577-2585.

Roussel, Y., Pebay, M., Guédon, G., Simonet, J.-M. \& Decaris, B. (1994). Physical and genetic map of Streptococcus thermophilus A054. J Bacteriol 176, 7413-7422.
Roussel, Y., Bourgoin, F., Guédon, G., Pebay, M. \& Decaris, B. (1997). Analysis of the genetic polymorphism between three Streptococcus thermophilus strains by comparing their physical and genetic organization. Microbiology 143, 1335-1343.

Salema, M., Lolkema, J. S., San Romão, M. V. \& Loureiro Dias, M. C. (1996). The proton motive force generated in Leuconostoc oenos by L-malate fermentation. J Bacteriol 178, 3127-3132.

Santos, R. (1995). Temperate bacteriophages of Leuconostoc oenos. PhD thesis, University of Lisbon.

Santos, R., Vieira, G., Santos, M. A. \& Paveia, H. (1996). Characterization of temperate bacteriophages of Leuconostoc oenos and evidence for two prophage attachment sites in the genome of starter strain PSU-1. J Appl Bacteriol 81, 383-392.

Sesma, F., Gardiol, D., Holgado, A. P. \& de Mendonza, D. (1990). Cloning of the citrate permease gene of Lactococcus lactis subsp. lactis biovar diacetylactis and expression in Escherichia coli. Appl Environ Microbiol 56, 2099-2103.

Smith, C. L. \& Condemine, G. (1990). New approaches for physical mapping of small genomes. J Bacteriol 172, 1167-1172.

Sulivan, M. A., Yasbin, R. E. \& Young, F. E. (1984). New shuttle vectors for Bacillus subtilis and Escherichia coli which allow rapid detection of inserted fragments. Gene 29, 21-26.

Tenreiro, R., Santos, R., Brito, L., Paveia, H., Vieira, G. \& Santos, M. A. (1993). Bacteriophages induced by mitomycin $C$ treatment of Leuconostoc oenos strains from Portuguese wines. Lett Appl Microbiol 16, 207-209.

Tenreiro, R., Santos, M. A., Paveia, H. \& Vieira, G. (1994). Interstrain relationships among wine leuconostocs and their divergence from other Leuconostoc species, as revealed by low frequency restriction fragment analysis of genomic DNA. J Appl Bacteriol 77, 271-280.

Tulloch, D., Finch, L. R., Hillier, A. J. \& Davidson, B. (1991). Physical map of the chromosome of Lactococcus lactis subsp. lactis DL11 and localization of six putative rRNA operons. J Bacteriol 173, 2768-2775.

Veiga da Cunha, M., Santos, H. \& van Schaftingen, E. (1993). Pathway and regulation of erythritol formation in Leuconostoc oenos. J Bacteriol 175, 3941-3948.

Viti, C., Giovannetti, L., Granchi, L. \& Ventura, S. (1996). Species atribution and strain typing of Oenococcus oeni (formerly Leuconostoc oenos) with restriction endonuclease fingerprints. Res Microbiol 147, 651-660.

Wahl, G. M., Meinkoth, J. L. \& Kimmel, A. R. (1987). Northern and Southern blots. Methods Enzymol 152, 572-581.

Zavaleta, A. I., Martinez-Murcia, A. J. \& Rodriguez-Valera, F. (1996). 16S-23S rDNA intergenic sequences indicate that Leuconostoc oenos is phylogenetically homogeneous. Microbiology $142,2105-2114$

Zavaleta, A. I., Martinez-Murcia, A. J. \& Rodriguez-Valera, F. (1997). Intraspecific genetic diversity of Oenococcus oeni as derived from DNA fingerprinting and sequence analyses. Appl Environ Microbiol 63, 1261-1267.

Zúniga, M., Pardo, I. \& Ferrer, S. (1996). Nucleotide sequence of plasmid p4028, a cryptic plasmid from Leuconostoc oenos. Plasmid 35, 67-74.

Received 11 November 1997; revised 5 January 1998; accepted 14 January 1998. 